\title{
BROKEN EUROPE. THE INTERNATIONAL ORDER IN CENTRAL AND EASTERN EUROPE*
}

\author{
by Marek Pietraś
}

After the collapse of the bipolar international system, a new line of "soft" division in Europe has been established in East-Central Europe. The article seeks to verify the hypothesis that Central and Eastern Europe is an international relations area but is not a cohesive, tightly-knit region united by common institutions, historical experience and the resulting awareness of a separate identity and a sense of community vis-à-vis the external world whereas the international order herein is a dynamic process undergoing evolution. Despite the passage of over twenty years since the collapse of the bipolar system, this process has not yet been completed.

This area, Oskar Halecki (cited below) wrote, is situated between Russia and Germany and between Sweden and Turkey. It has indeterminate orders and is an area of dynamic but asymmetric (from the geographical and intensity perspective) transformation processes "from communism"

* Paper based on M. Pietraś, Europa Środkowo-Wschodnia w strukturze ładu międzynarodowego, [in:] H. Chałupczak, M. Pietraś, P. Tosiek (eds.), Europa ŚrodkowoWschodnia w procesie transformacji i integracji. Wymiar polityczny, Zamość 2010, pp. 11-36 and M. Pietraś, Evolution of international order in East-Central Europe, "Global and Strategies" 2012, No. 1. 
towards democracy, market economy and modernization. It is the asymmetry of the pace, content and geographical extent of the transformation processes that prevents this area from being a cohesive region which is subject to specific "cracking" and "halving"; consequently, individual countries participate in the integration processes with different intensity. This also means that after the termination of the Cold War the process of formation of the international order in this part of Europe has not finished: Some Central and Eastern European countries are integrated with the Euro-Atlantic structures while those of the pro-Soviet area have become a stake in the game of international influences, having at the same time a low level of political standards characteristic of democratic societies.

In the context of the aforementioned specificity of the Central and Eastern European area the goal of the article is to analyze the evolution of the international order in the area, having assumed that the internal transformation processes are one of the factors that mold the functioning of the international environment. Four elements are regarded as especially vital for the forming and functioning of the international order in postCold War Europe. These are as follows: the system of shared political values but also modernization, the system of institutional ties, and the system of accepted norms and the structure of alignment. The object of analysis was also the geographic range of the Central and Eastern European area.

\section{THE GEOGRAPHICAL RANGE OF THE CENTRAL AND EASTERN EUROPEAN AREA}

The geographical range of the area called Central and Eastern Europe - the object of disputes and controversies - is not clear-cut and precisely defined although Jerzy Kłoczowski believes that the notion of "Central and Eastern Europe" has been accepted by various historical schools ${ }^{1}$. A significant contribution to the thinking in this area and its identification

1 J. Kłoczowski, Europea Środkowo-Wschodnia w przestrzeni europejskiej, http://jazon.hist.uj.edu.pl/zjazd/materialy/kloczowski.pdf. 
was made by Oskar Halecki. The concept of Central and Eastern Europe which he proposed was to capture the specific and separate identity of the eastern part of Central Europe, which was different in terms of culture and historical experience from the western part of Central Europe formed by the German-speaking area. In this context, Halecki believes, Central and Eastern Europe is the area between Sweden, Germany and Italy on the one side, and Turkey and Russia on the other ${ }^{2}$.

While Oskar Halecki focused on delineating the area, or more precisely, on the boundaries of space called Central and Eastern Europe, others attempted to identify the countries which make up this area. Robert Magocsi, however, used an intermediate solution by defining zones in Central and Eastern Europe and the countries that function within them. He distinguished the Northern zone, Alpine-Carpathian zone and the Balkan zone. He included Poland, Lithuania, Belarus, Ukraine, Moldova and the former East German area in the Northern zone. The AlpineCarpathian zone consisted of the Czech Republic, Slovakia, Austria, Hungary, Romania, Slovenia, a part of Croatia and a part of Serbia as well as Bosnia and Northern Italy, while the Balkan zone consisted of South Croatia, South Serbia, Bosnia and Herzegovina, Montenegro, Macedonia, Bulgaria, Albania, Greece and the European part of Turkey ${ }^{3}$. Robert Magocsi thus delineated the broader boundaries of the Central and Eastern European area than Oskar Halecki did.

A similar thinking trend, which consists in defining the borders of the area and identifying its countries, is represented by Columbia University's East Central European Center in New York. This term applies to the area between Germany and Russia, and between the Baltic and the Aegean Sea. This area comprises the following countries: Albania, Austria, Belarus, Bosnia and Herzegovina, Bulgaria, Croatia, the Czech Republic, Estonia, Slovakia, Slovenia, Hungary, Lithuania, Moldova, Hungary, Lithuania, Latvia, Macedonia, Montenegro, Poland, Romania, Serbia and Ukraine ${ }^{4}$.

2 O. Halecki, Borderlands of Western Civilization. A History of East Central Europe, New York 1952 (electronic version).

3 R. Magocsi, Historical Atlas of East-Central Europe, Seattle 1993.

4 Columbia University, East Central European Center, http://www.columbia.edu/cu/ ece/about/mission.html. 
The Centre D'Étude de L'Europe Mediane [Central European Studies Center] in Paris in turn regards this area as the one between Russia and Germany and between the Baltic Sea region and the Balkan area. The Center's studies cover 17 cultures: Bosnian, Bulgarian, Croatian, Estonian, Hungarian, Lithuanian, Latvian, Macedonian, Montenegrin, Polish, Rumanian, Serbian, Slovak, Slovene, Czech and Ukrainian ${ }^{5}$.

Jerzy Kłoczowski, when defining the spatial extent of Central and Eastern Europe, referred to the common historical experience and concluded that this was the area which was part of the Commonwealth of Both Nations [i.e. Poland] and the historical kingdoms of Bohemia and Hungary for many centuries. Currently, this area consists, in his interpretation, of Poland, Lithuania, Belarus, Ukraine, the Czech Republic, Slovakia, Hungary, Croatia and a large part of Romania 6 .

In the attempts to define the Central and Eastern European area there is generally a common consent that this is the space between Germany and Russia. The controversies mainly concern the boundaries of this area along the North-South axis. It does not seem justified here to include Greece and the European part of Turkey in Central and Eastern Europe in the south as Paul Magocsi did. The least controversial appears Oskar Halecki's attempt to identify the area of Central and Eastern Europe and the identification of the countries belonging to this area carried out by Columbia University's East Central European Center. In the latter case it may be debatable, taking into account historical experience, cultural traditions and political standards, to have included Austria in this area. On the other hand, it is necessary to include Kosovo.

\footnotetext{
5 Centre D’Étude de L’Europe Mediane, http://www.ceem.fr.

${ }^{6}$ J. Kłoczowski, Wprowadzenie, [in:] Historia Central and Eastern Europe, ed. J. Kłoczowski, Lublin 2000, vol. 1, p. 7.
} 


\section{THE ESSENCE AND SPECIFICITY OF THE INTERNATIONAL ORDER IN CENTRAL AND EASTERN EUROPE ${ }^{7}$}

The concept of the international order, despite being the subject of intense studies, is seldom defined. For centuries many philosophers and thinkers interpreted order as a value because it was identified with the opposite of chaos, anarchy, disorder or spontaneity. In the positive sense it was identified with lawful order, internal cohesion and equilibrium ${ }^{8}$.

This identification of the concept of order is apparently connected with its popular, positive meaning. However, for the purpose of scientific analyses it is necessary to interpret it in "neutral" terms. Hence "international order" should be identified with a set of structures, mechanisms, distribution of forces, actors and their interests, values, etc. which define the way or organization and the functioning of the international environment in a particular period. This is the way of the international order's organization that determines the conditions of coexistence of participants in international relations, especially the states (countries). The order thus understood is possible in the polyarchic, decentralized, or, as some would rather call it, anarchic international environment, which creates the structural framework for all international phenomena and processes. Consequently, there is no contradiction between the polyarchic character of the international environment and the international order.

With the absence of a generally acceptable definition of the international order the dominant mode of its description is to identify its elements or the constituents of the structure and functioning i.e. the content of order in a particular period. Józef Kukułka named the following: the degree of institutionalization of the international environment, preferred values, especially by the main participants in international relations, and the structure of interests and aspirations of countries, particularly those of a power status. These elements do not exhaust, however, the complexity of the international environment's organization within the formula of

7 Prepared using M. Pietraś, Pozimnowojenny international order, [in:] Międzynarodowe stosunki polityczne, ed. idem, Lublin 2007, p. 294 et seq.

8 See J. Kukułka, Pojęcie i istota międzynarodowego ładu pokojowego, [in:] Problemy międzynarodowego ładu pokojowego, Warszawa 1987, p. 10. 
the international order. Its analysis requires that we combine into a coherent whole such elements as the polarity of the international environment or the existing distribution of power, the set of preferred values, norms and behavioral patterns, institutional ties in the form of international organizations and the dominant evolutionary tendencies. These elements make up the structure of the international order as the sphere of reality and the structure of its analysis.

Apart from defining the structure, an important element of the characteristics of the post-Cold War international order is to define its specificity. Despite the lapse of over a dozen years since the end of the Cold War, the international order in Central and Eastern Europe has still been taking shape. Therefore, it has been in the process of transformation and evolution. The transparency and unambiguous nature of the order in this part of Europe which was characteristic of the Cold War period no longer exist. At the military-political and ideological levels at that time, the global order, in particular in Europe, was characterized by bipolarity while Central and Eastern Europe, except the Yugoslavian area, was part of the Eastern pole (=bloc). At the level of institutional ties it could be defined in terms of the three-part system or the division into: first, NATO countries, contemporary EEC and the Council of Europe; second, Warsaw Pact countries and the COMECON; and, third, neutral and non-aligned countries $(\mathrm{N}+\mathrm{N})$. In terms of institutional ties, Central and Eastern Europe was divided between the Warsaw Pact and COMECON on the one side, and the $\mathrm{N}+\mathrm{N}$ countries on the other.

An essential feature of the order at that time was the presence - decisive for its structure and functioning - of world powers: one non-European (USA) and the other only partly European (the former Soviet Union). This significantly restricted Europe's international actor status and its political identity. That condition applied particularly to a large part of Central and Eastern Europe, which remained in the zone of influence of the former Soviet Union. While the present order in the Euro-Atlantic area (despite a radical change) is developing, which may appear paradoxical, through the retention and adjustment of many elements of the old order, especially at the level of institutional ties, the order in Central and Eastern Europe is being shaped by rejecting the elements of the old order and by develop- 
ing new solutions, and /or by joining the Western European structures. This means that while the development of the order in the Euro-Atlantic area is characterized by the process of changes but also the continuation and adjustment of old elements to the new realities of the international environment, the dominant tendency in Central and Eastern Europe is that of change because the structures of the old order have ceased to exist. Józef Kukułka points out that the new order is not merely a simple rejection of the old one but is its resumption under new circumstances. He adds that the new order is not a simple antithesis of the old order but it constitutes the new synthesis of the permanent elements of the order's past and new elements of its structure ${ }^{9}$. This view seems correct in reference to the Euro-Atlantic order. Here, the process of creation and the functioning of the post-Cold War international order are characterized by the elements of continuity and change. By contrast, in Central and Eastern Europe the dominant tendency is to change and develop new, previously unknown solutions.

An important feature of the emerging order - also in Central and Eastern Europe - is the process of negotiating it and recourse to diplomatic efforts rather than imposition. This is a significant change when compared to historical experience. In the past, changes in the international order were first of all the result of winning a war for hegemony by some powers and losing it by others. The new hegemonic power/powers imposed their order in accordance to their preferences. These were the principles that shaped the international order after the conclusion of the Westphalian Treaty in 1648, which ended the Thirty Years' War. This was also the case after the Vienna Congress in 1815, which ended the period of Napoleonic wars and established the so-called Concert of Powers. After World War I the foundations of contemporary international order were created by the Treaty of Versailles concluded in 1919, and after World War II - by the Yalta-Potsdam agreements concluded in 1845. At present, although the Cold war ended in the victory of one superpower and the collapse of the

${ }^{9}$ J. Kukułka, Na drodze do nowego ładu światowego, [in:] Krajobraz po transformacji. Środowisko międzynarodowe Polski lat dziewięćdziesiątych, ed. R. Kuźniar, Warszawa 1992, p. 197. 
other, the process of developing the international order mainly through diplomatic efforts is still continuing and will do so. We should expect that this will create grounds for its permanence and stability in the future. This assessment has not been altered by the view according to which the postCold War international order ended after the terrorist attacks of 11 September 2001 and a new stage of its functioning commenced, while Russia, in her nostalgic policy of rebuilding her former power, uses neo-imperial rhetoric and tries to regain her previous zones of influence.

The specific character of the emerging international order is also defined by the overcoming of the previous traditions of its state-centric interpretation. This order is becoming more pluralistic in respect of the subjects/actors that create it; consequently, it is becoming increasingly decentralized. It is necessary therefore to take into consideration the nongovernment actors associated with the empowerment of social groups or even individuals in the international environment the more so because their development is an element of the objective dynamism and change in this environment. The post-Cold War international order has thus a two-level structure. This is the "world of states" and the "world of nongovernmental actors" with the clear and unquestionable position and role of the former ${ }^{10}$. This feature also applies to Central and Eastern Europe ${ }^{11}$.

The analysis of the specificity of the international order also requires that we define its utilitarian aspect i.e. identify the pragmatic logic of its functioning. During the Cold War the usefulness and at the same time the logic of functioning of the so-called Yalta-Potsdam order was oriented towards preserving the contemporary political and territorial status quo. What does the utilitarian aspect of the international order currently being formed consist of, especially in the Euro-Atlantic area? It appears that the main value protected within this order and by this order is the stability of

10 See M. Pietraś, K. Piórko, Podmioty transnarodowe, [in:] Międzynarodowe stosunki..., p. 139 et seq.; P. Willets, Aktorzy transnarodowi i organizacje międzynarodowe w polityce globalnej, [in:] Globalizacja polityki światowej. Wprowadzenie do stosunków międzynarodowych, eds. J. Baylis, S. Smith, Kraków 2008; J.N. Rosenau, Patterned Chaos in Global Life: Structure and Process in the Two Worlds of World Politics, "International Political Science Review" 1988, No. 4, pp. 327-364.

11 Transnational Actors in Central and East European Transitions, Pittsburgh 2008. 
the international environment or the ability to preserve its basic parameters under the conditions of progressive dynamism and change. In particular, it is the question of counteraction against sudden, non-linear and unpredictable changes. The stability of the international environment thus means striving to make it more predictable, which in turn creates grounds for the optimization of decisions and actions of countries but also of other participants in international relations. The special significance of stability and stabilization in the international environment for the post-Cold War order is shown for example by the use of these notions interchangeably with the term of international security.

In the Euro-Atlantic area the theme of stability and stabilization of the international environment seems to be a constant element of the thinking processes and of actions undertaken by the main international organizations such as OSCE, NATO, the European Union or the Council of Europe. This thinking and the actions that go with it are first of all a response to the destabilizing processes in the international environment in Central and Eastern Europe. In their context, Ziemowit J. Pietras wrote that the integration of the West and the disintegration of the East at the close of the $1980^{\text {s }}$ and in the early $1990^{\text {s }}$ resulted in the disappearance of polarity in its previous form of confrontation of the two blocs, and in the abandonment of former logic of developing the international relations, which, consequently, became chaotic and plunged into a state of functional and structural imbalance ${ }^{12}$. The reaction to this condition of the international environment in Central and Eastern Europe were the suggestions for and visions of its stabilization. Stability meaning predictability and the comparative ability to control changes in the environment became a value per se. In the case of the OSCE the Charter of Paris for a New Europe of November 1990 already outlined a vision of a peaceful and stable Europe ${ }^{13}$. The July 1992 CSCE Helsinki Summit documents pointed out that the

12 Z.J. Pietraś, Wyłanianie się Nowego Ładu Międzzynarodowego, [in:] Historia polityka - stosunki międzynarodowe. Ksiega jubileuszowa na 65-lecie Profesora Józefa Kukułki, Warszawa 1994, p. 214.

13 Charter of Paris for a New Europe, http://www.osce.org/mc/39516. 
goal of the participant countries was to strengthen security and stability ${ }^{14}$, while the Charter for European Security adopted at the OSCE Summit in Istanbul in November 1999 treated stability as a value, which was to be attained by a vast array of actions provided for in this document. These comprise inter alia the safeguarding of human rights, including those of national minorities; the development of confidence building measures; implementations of the 1990 CFE Treaty provisions concerning conventional disarmament; activities of international organizations, or democratization of socio-political life inside the countries ${ }^{15}$.

Since the early $1990^{\text {s }}$ the stability theme has been a constant element in NATO's structure of thinking and actions. The documents of the NATO Rome Summit in November 1991 pointed to the Alliance as the source of stability and the necessary guarantor of its members' security, and further stated that in the radically changed situation in Europe the formulated new strategic conception would enable implementation of a complete and comprehensive approach to the issues of stability and security. During the Washington Summit in April 1999 it was pointed out that the Alliance was central in the efforts to develop new models of cooperation and mutual understanding in the Euro-Atlantic area and committed itself to new actions for stability. It was also stated that NATO contributed not only to the defense of its members but also to peace and stability in the area.

Since the beginning of the $1990^{\text {s }}$ the problem of stability and stabilization of the international environment has been present in the political thinking and activities of the European Union, which has been promoting the stability of the Central and Eastern European area since the early 1990s, shifting its actions further into the east. This has been repeatedly stated in the Council of Europe's documents, in particular in connection with the development of the Common Foreign Policy and Security Policy, with the coverage of Central and Eastern European countries by the integration process, and with the development of the European Neighborhood Policy,

14 The Challenges of Change. CSCE Helsinki Document 1992, http://www.osce.org/ $\mathrm{mc} / 39530$.

15 Charter for European Security, Istanbul, November 1999, http://www.osce.org/ $\mathrm{mc} / 17502$. 
placing particular emphasis on its eastern dimension and the Eastern Partnership initiative. In 1995, on the initiative of France as an EU member state the Stability Pact was signed, whose aim was essentially to stabilize the borders in Central and Eastern Europe and prevent a situation in which ethnic problems might become the cause for claims for border adjustments. In June 1999, in turn, during the Council of Europe Summit in Cologne the Stability Pact for South-Eastern Europe was adopted. It provides the foundations for multi-dimensional actions, including economic aid, for stabilizing the situation in the Balkans after the cessation of the NATO operation in Kosovo ${ }^{16}$

\section{VALUES AS AN ELEMENT OF THE INTERNATIONAL ORDER IN CENTRAL AND EASTERN EUROPE}

Despite the ambivalent assessment concerning the essence of the Cold War and the dilemma whether this was a rivalry between superpowers for hegemony or a conflict of two opposing ideologies, it was values that underlay the contemporary divisions, especially in the Euro-Atlantic area. Hence the process of its unification began with the definition of the catalog of common vales around which the process of the "interior organization" of European countries occurs and they achieve their cohesion at least in the minimal dimension. The first significant step in that direction was made during the CSCE Paris Summit in November 1990. The then adopted Charter of Paris for a New Europe highlighted such values as democracy, market economy, rule of law, observance of human rights, including those of national minorities, and environmental responsibility ${ }^{17}$. They were accepted by all the European countries participating in the Conference, including Central and Eastern European. In this way, after the end of the Cold War, the Euro-Atlantic area, including Central and Eastern Europe, was being formed as a community of political values ${ }^{18}$.

\footnotetext{
16 Stability Pact for South-Eastern Europe, http://www.stabilitypact.org/constituent /990610-cologne.asp.

17 Charter of Paris for a New Europe, http://www.osce.org/mc/39516.

18 See M. Pietraś, Ład międzynarodowy..., p. 299.
} 
As compared with the Cold War period the situation creates a new quality and is an element of change in the international order in the EuroAtlantic area. At the same time this change provides grounds for strengthening stability because the community of fundamental political values eliminates the opportunity for ideological confrontation. Furthermore, when it is the interior of a country that is currently the main source of destabilization of the international environment, ${ }^{19}$ its homogeneity "organized" in relation to shared values essentially increases the predictability of individual countries' behavior and is a source of stability in the EuroAtlantic area.

However, Central and Eastern Europe functions in a specific way in the Euro-Atlantic area as a community of political values. The organization of socio-political and economic life in this part of Europe in accordance with the liberal political values that functioned in Western Europe even during the Cold War period is the substance of the process of systemic transformation. This denotes the process of political adjustment of the state's political organization and society to liberal-democratic standards with the simultaneous implications of this fact for the functioning in the international environment and the shaping of its organization or order. This means that the feature of the present-day international environment is that the international order arises from within the states. In Poland, the process of systemic transformation caused this country, "oriented" towards the East during the Cold War, to turn into a country "oriented" towards the West, integrated with the NATO, EU, Council of Europe and OECD, etc.

In Central and Eastern Europe the specific functioning of common political values is defined by the general formal acceptance of liberaldemocratic political standards and the varied level of political practice and political culture associated with the implementation of these principles. This level is higher in the central part of Central and Eastern Europe and far lower in the eastern part. This is explicitly confirmed by, for example, the OSCE Office for Democratic Institutions and Human Rights reports concerning the assessment of the conducted parliamentary and

19 See J.N. Rosenau, Along the Domestic - Foreign Frontier. Exploring Governance in a Turbulent World, Cambridge 1997. 
presidential elections (see Table 1). Observations pertaining to violations of OSCE international standards of holding elections were also formulated towards new EU member states of Central and Eastern Europe. Reservations were aimed, however, at the pro-Soviet countries, in particular: Belarus, Ukraine and Moldova, and the Balkan countries, e.g. Albania and Macedonia. There is thus clear asymmetry in the practice of implementation of formally accepted political standards. Charles Gati even expressed a view that under the conditions of the spread of democracy from Central Europe towards the post-Soviet area, the zone of the functioning of democratic institutions broadens, which, however, does not mean the widening of the zone democracy culture. In his opinion this shows that the transformation "from communism" has been brought to an end but at the same time the transformation "towards the culture of democracy" has not ended and the process is still going on ${ }^{20}$. This is a huge challenge for the process of granting membership by the Euro-Atlantic institutions to many countries in the area. This process can take place in conditions of the absence of broadened democratic culture with the occurrence of strong nationalist tendencies at the same time, with the absence of civil society structures and a longing for the welfare State and strong-arm government.

The opinions on not only the absence of progress in the development of democratic standards but also on their regression in Eastern European countries are confirmed by the European Union's assessments. In its 2010 communiqué on the implementation of the European Neighborhood Policy, the European Commission stated that in the countries covered by this policy, including those in Eastern Europe, the formal acceptance of fundamental human freedoms and rights is accompanied by problems with their implementation. It was emphasized, which is particularly confirmed by the example of Belarus, that there is no progress in reducing the use of torture, in the freedom of expression and independence of the

\footnotetext{
20 See Ch. Gatti, The unfinished revolution: East-Central Europe, democratization and the Euro-atlantic community, "In the National Interest", 5.02.2003.
} 
media, and the freedom of assembly. The progress in the development of civil society was also found to be limited ${ }^{21}$

Table 1: Assessment of elections in selected Central and Eastern European countries based on the reports of the Warsaw-based OSCE Office for Democratic Institutions and Human Rights

\begin{tabular}{|c|c|c|}
\hline Country & $\begin{array}{l}\text { Date and type } \\
\text { of elections }\end{array}$ & Assessment \\
\hline Albania & $\begin{array}{l}2001 \text { - parliamentary } \\
2005 \text { - parliamentary } \\
2009 \text { - parliamentary }\end{array}$ & $\begin{array}{l}\text { - Violations of standards } \\
\text { - Only partly satisfied OSCE and Council of Eu- } \\
\text { rope standards } \\
\text { - Conforming to most OSCE standards, showing } \\
\text { considerable progress but still not fully democra- } \\
\text { tic }\end{array}$ \\
\hline Belarus & $\begin{array}{l}2006 \text { - presidential } \\
2008 \text { - parliamentary } \\
2010 \text { - presidential }\end{array}$ & $\begin{array}{l}\text { - Lack of identical conditions for competition } \\
\text { between candidates. } \\
\text { - Lack of genuine political competition and lack } \\
\text { of equal treatment of political parties } \\
\text { - Lack of independence of administration orga- } \\
\text { nizing elections, absence of transparency of the } \\
\text { election process, jailing of opposition candidates } \\
\text { on election night. }\end{array}$ \\
\hline Bulgaria & $\begin{array}{l}2001 \text { - parliamentary } \\
2006 \text { - presidential } \\
2009 \text { - parliamentary }\end{array}$ & $\begin{array}{l}\text { - Conforming to international elections but im- } \\
\text { provement is possible } \\
\text { - Standards fulfilled but society not interested in } \\
\text { the election campaign } \\
\text { - Generally conforming to OSCE and Council of } \\
\text { Europe standards }\end{array}$ \\
\hline $\begin{array}{l}\text { Czech } \\
\text { Republic }\end{array}$ & 2002 - parliamentary & - Elections were declared democratic \\
\hline Lithuania & 1996 - parliamentary & $\begin{array}{l}\text { - Negligence in implementation of international } \\
\text { standards }\end{array}$ \\
\hline Macedonia & 2008 - parliamentary & $\begin{array}{l}\text { - Elections declared democratic although slight } \\
\text { infringements occurred }\end{array}$ \\
\hline
\end{tabular}

21 Communication from the Commission to the European Parliament and the Council. Taking stock of the European Neighbourhood Policy, COM (2010) 207. 


\begin{tabular}{|l|l|l|}
\hline Country & $\begin{array}{l}\text { Date and type } \\
\text { of elections }\end{array}$ & Assessment \\
\hline Moldova & $\begin{array}{l}2005-\text { parliamentary } \\
\text { 2010 - parliamentary }\end{array}$ & $\begin{array}{l}\text { - Declaration of support in order to attain OSCE } \\
\text { and Council of Europe standards } \\
\text { - Conforming to most OSCE and Council of Eu- } \\
\text { rope standards }\end{array}$ \\
\hline Poland & 2007 - parliamentary & $\begin{array}{l}\text { - Campaign defined as emotional, divisive, with } \\
\text { elements of the Government's partial interven- } \\
\text { tion. Lack of equal treatment of parties by public } \\
\text { TV }\end{array}$ \\
\hline Romania & $\begin{array}{l}2004-\text { parliamentary } \\
\text { and presidential } \\
2009-\text { presidential }\end{array}$ & $\begin{array}{l}\text { - Conforming to OSCE standards } \\
\text { - Generally conforming to OSCE standards }\end{array}$ \\
\hline Slovakia & $\begin{array}{l}2002 .- \text { parliamentary } \\
2010-\text { parliamentary }\end{array}$ & $\begin{array}{l}\text { - Conforming to democratic standards } \\
\text { Conducted with respect for fundamental rights } \\
\text { and freedoms }\end{array}$ \\
\hline Ukraine & $\begin{array}{l}2007-\text { parliamentary } \\
\text { - Conducted largely in conformity with interna- } \\
\text { tional standards. } \\
\text { - Conforming to the majority of OSCE standards }\end{array}$ \\
\hline Hungary & $\begin{array}{l}2002-\text { parliamentary } \\
2010-\text { parliamentary }\end{array}$ & $\begin{array}{l}\text { - Conforming to international standards. } \\
\text { The elections confirmed democratic values } \\
\text { developed in Hungary in the last 20 years. }\end{array}$ \\
\hline
\end{tabular}

Source: Author's own compilation based on over a dozen of ODIHR reports.

Actions for the promotion of European political standards in Eastern European countries are undertaken by the European Union. Especially important is the Eastern Partnership, which has been implemented by the EU since 2009 on the initiative of Poland and Sweden. It also covers such countries as Ukraine, Moldova, Belarus as well as Armenia, Azerbaijan and Georgia. It is part of the EU's conception and practice of the European Neighborhood Policy (implemented by the EU since 2004, i.e. when the EU's borders were widened and extended to the east), which is aimed not only at Eastern European countries but also at the non-European ones around the Mediterranean basin. Altogether, this covers fifteen states and the Palestinian Autonomy.

In the context of evolution of the international order in Central and Eastern Europe the Eastern Partnership is a vital initiative, at least for two 
reasons. First, this means that in the long run (a difficult-to-predict perspective) the strategy of ensuring the European Union's stability and security of the international environment by the process of incorporating new member countries, which happened in 2004 and 2007, has exhausted its possibilities. The goal of the Eastern Partnership is not, as Poland would have it, to prepare the countries for which it is intended for membership although this cannot be excluded in the long run. Second, the prospect for EU membership of Eastern European countries seems to be replaced by the project perspective, which is accompanied by the EU's conviction that it is possible to secure its security by encouraging neighbours to introduce the political values and institutional solutions which function in the EU ${ }^{22}$. The aim of these actions is therefore to attempt to alleviate the negative effects of the shift of borders in Europe's division further into the east by stimulating the transformation processes, striving to stabilize the internal situation and relations in these countries inter alia by promoting democratic values. However, the practice of previous actions shows that while trying to implement this goal we are not only failing to achieve progress but witnessing regression. This means that the process of political transformation in the former Soviet bloc countries is far more complex than the transformation process in the post-communist Central European countries which joined the North Atlantic Alliance and the European Union. What seems to be a significant barrier is the inherited type of political culture and the oligarchic structures associated with it and characteristic of many Eastern European countries.

Of special importance for the preservation of the international order in post-Cold War Europe and its stability is becoming the protection of human rights. It is becoming the chief element of Europe's political identity and is clearly gaining prominence over the principle of states' sovereignty and non-interference in their internal affairs. It has been decided that where violation of human rights can be the source of destabilization of the international environment, countries cannot invoke the principle of non-interference in their internal affairs.

22 See I. Krastev, M. Leonard, Widmo Europy wielobiegunowej [translated from The Specter of a Multipolar Europe] Warszawa 2011. 
However, the practice of respecting human rights in Central and Eastern European countries is the subject of criticism, for example by nongovernmental organizations. In its annual reports Amnesty International identifies and criticizes the cases of human rights violations on a global scale, taking into account the Central and Eastern European countries. On the basis of analyses of the 2009 and 2011 reports we can conclude that the intensity of human rights violation varies in individual countries in this part of Europe. There seems, however, to be a clear dividing line between the Central and Eastern European countries-members of the European Union and those outside it. In the former the level of observance of human rights standards is higher than in the latter, each of the countries having its specific problems. In the case of the Czech Republic, the main problem emphasized in the Amnesty International reports is discrimination against the Romany community ${ }^{23}$. Similarly, Slovakia has been accused of discriminating against the Romany community in the fields of education, housing and access to the healthcare system ${ }^{24}$. The main accusation against Poland is discrimination against sexual minorities and the consent of secret CIA prisons in connection with US actions against terrorist organizations ${ }^{25}$. Similar charges have been levied against Romania, with additional accusation of unjustified use of coercion by public officials and discrimination against the Romany community as well as failure to observe the rights of sexual minorities ${ }^{26}$.

Entirely different accusations were leveled in the Amnesty International 2009 reports against the Central and Eastern European countries which are non EU member states. In 2009 Belarus was accused of excessive control over society, the growing control of the public media and restric-

\footnotetext{
${ }^{23}$ Human rights in Czech Republic, http://www.amnesty.org/en/region/czech-republic/report-2009; Annual Report 2011 Czech Republic, http://www.amnesty.org/en/region/ czech-republic/report-2011.

24 Human rights in Slovak Republic, http://www.amnesty.org/en/region/slovak-republic/report-2009; Annual Report 2011, Slovakia, http://www.amnesty.org/en/region/ slovak-republic/report-2011.

25 Human rights in Republic of Poland, http://www.amnesty.org/en/region/poland/ report-2009.

26 Human rights In Romania, http://www.amnesty.org/en/region/romania/report-2009.
} 
tions against the independent media. There were also accusations of restricting the right to assemble in public, and jailing of participants in peaceful demonstrations. The reports stated that civil society activists and independent journalists were persecuted. Belarus was also accused of the execution of the death penalty, four such cases being pointed out in $2009^{27}$. The 2011 report confirmed most of the earlier charges. It again emphasized restrictions on the freedom of expression, freedom to assemble, the detention of political prisoners, and sentencing to and execution of the death penalty ${ }^{28}$. Ukraine was accused in the 2009 report of failure to effectively counter growing racist attacks, compulsory sending back of refugees and asylum-seeking persons, the use of torture during police interrogations and impunity of those responsible for violating human rights ${ }^{29}$. These charges were repeated in the 2011 report $^{30}$. The 2009 report accused Moldova, like Ukraine, of the use of torture and failure to punish those responsible for violating human rights. The perpetrators of racial discrimination went unpunished. It stated that new regulations on the freedom to assemble were not implemented ${ }^{31}$. These accusations were confirmed in the 2011 report, adding the failure to respect the rights of sexual minorities ${ }^{32}$. Bosnia and Herzegovina, in turn, were accused of growing nationalist rhetoric, the low level of punishment for war criminals and the unsatisfactory level of counteraction against attacks on sexual minorities ${ }^{33}$.

27 Human rights in Republic of Belarus, http://www.amnesty.org/en/region/belarus/ report-2009.

28 Annual Report 2011, Belarus, http://www.amnesty.org/en/region/belarus/report-2011.

${ }^{29}$ Human rights in Ukraine, http://www.amnesty.org/en/region/ukraine/report-2009

30 Annual Report 2011, Ukraine, http://www.amnesty.org/en/region/ukraine/report-2011.

31 Human rights in Moldova, http://www.amnesty.org/en/region/moldova/report-2009.

32 Annual Report 2011, Moldova, http://www.amnesty.org/en/region/moldova/report-2011.

33 Human rights in Bosnia and Herzegovina, http://www.amnesty.org/en/region/ bosnia-herzegovina/report-2009. 
The analysis of Amnesty International reports provides grounds for a conclusion that the formal acceptance of human rights standards in the Central and Eastern European area is accompanied by different levels of implementation practice. There is a distinct dividing line, a characteristic crack, between the European Union countries and the former Soviet Union states. Specific problems being the observance of human rights, mainly in the context of the legacy of recently ended wars, occur in the Balkan countries. Consequently, in terms of the observance of human rights standards, the Central and Eastern European area is not a unified, cohesive region.

It appears, however, that the analysis of political values associated with the process of transition from real socialism to liberal democracy, regardless of defects that go with this process, does not exhaust the complex problem of values as a criterion for the assessment of the international order in the Central and Eastern European area and the position of these countries in the structure of the international area. Apart from its political transformation, the international order in this area and the position of the local countries in the structure of the international order is also defined by the process of their economic transformation and modernization. In the conditions of globalization processes and with the growing role of the technological factor and economic processes in the development of social life, ${ }^{34}$ modernization is becoming a value which at the same time reflects the ability to adjust to the equalit of the new international environment. It is here that the countries and societies in Central and Eastern European area undergo the process of transition from agrarian-industrial or industrial agrarian economies to industrial and post industrial ones, with a high share of services and information society. It is therefore legitimate to ask about the position of this group of countries in the structure of the global economic and modernization processes.

One of the measures of civilization changes connected with the simultaneous processes of globalization and modernization is access to the Internet or its position in the cyberspace structure (see Table 2). The

34 See M. Pietraś, Globalization as a process of changing international community, [in:] The Faces of Globalization, ed. M. Pietraś, Lublin 2002. 
Internet access level in Central and Eastern European countries is distinctly higher in the EU member states than outside of it. In Poland in $2009,52 \%$ of society had access to the Internet while in $2011-58.4 \%$; in the Czech Republic: 59\% and 65.6\% respectively; in Slovenia $64.8 \%$ and $64.9 \%$, while in Hungary $59.3 \%$ and $61.9 \%$. In the pro-Soviet area access to the Internet in 2009 was as follows: in Ukraine $22.7 \%$ of society and in 2011-33.9\%; in Belarus 32.2\% and 46.3\% respectively; in Moldova. 19.7\% and $30.9 \%$. For comparison, in Austria in 2009 the figures for Internet access were $72.3 \%$ of society, and in $2011-74.8 \%$; in Belgium $70 \%$ and $77.8 \%$ respectively, in Denmark - $84 \%$ and $85.9 \%$, and in the Netherlands $85.6 \%$ and $88.3 \%$. The dividing line is thus very clear here, with the level of solutions and certain civilization values being "traditionally" far lower in the pro-Soviet area. We cannot fail to observe, however, that the dynamics of increase in the number of people having access to the Internet in the post-Soviet area is higher than in the Central European countries, not to mention Western European ones.

When analyzing values as the element of molding the international order in Central and Eastern Europe we should emphasize that there is a clear diving line in this area along the North - South axis. Furthermore, in respect of political standards, the observance of human rights standards and civilizational standards, for instance access to the Internet, this dividing line - the specific "crack" - appears to be reinforced, albeit to a lesser extent with regard to the Internet. This may mean a further shift into the east of the new line of division of Europe as compared with the one that existed during the Cold War. The more so because some Central and Eastern European countries, currently especially those in the Western Balkans, which have joined or are likely to join the European Union, are systematically raising their political and civilization standards. Consequently, these countries are shifting from the semi-peripheries of Western political and civilization standards towards the fringes of the EU's center. This is yet another confirmation that Central and Eastern Europe is not a cohesive region but an area of different, asymmetrical dynamics of development and position in the structure of globalization and the modernization processes. 
Table 2. Access to the Internet in Europe 2009

\begin{tabular}{|c|c|c|c|c|c|}
\hline \multirow{2}{*}{ Country } & \multirow{2}{*}{ Population } & \multicolumn{2}{|c|}{ Number of Internet users } & \multicolumn{2}{|c|}{ Access in $\%$} \\
\hline & & 2009 & 2011 & 2009 & 2011 \\
\hline Albania & $3,639,453$ & 750,000 & $1,300,000$ & $20.6 \%$ & 43.4 \\
\hline Austria & $8,210,281$ & $5,936,700$ & $6,143,600$ & $72.3 \%$ & 74.8 \\
\hline Belarus & $9,648,533$ & $3,106,900$ & $4,436,800$ & $32.2 \%$ & 46.3 \\
\hline Belgium & $10,414,336$ & $7,292,300$ & $8,113,200$ & $70.0 \%$ & 77.8 \\
\hline Bosnia-Herzegovina & $4,613,414$ & $1,441,000$ & $1,441,000$ & $31.2 \%$ & 31.2 \\
\hline Bulgaria & $7,204,687$ & $2,647,100$ & $3,395,000$ & $36.7 \%$ & 47.9 \\
\hline Croatia & $4,489,409$ & $2,244,400$ & $2,244,400$ & $50.0 \%$ & 50.1 \\
\hline Czech Republic & $10,211,904$ & $6,027,700$ & $6,680,800$ & $59.0 \%$ & 65.6 \\
\hline Dania & $5,500,510$ & $4,629,600$ & $4,750,500$ & $84.2 \%$ & 85.9 \\
\hline Estonia & $1,299,371$ & 888,100 & 971,700 & $68.3 \%$ & 75.7 \\
\hline Finland & $5,250,275$ & $4,382,700$ & $4,480,900$ & $83.5 \%$ & 85.2 \\
\hline France & $62,150,775$ & $43,100,134$ & $45,262,000$ & $69.3 \%$ & 69.5 \\
\hline Germany & $82,329,758$ & $54,229,325$ & $65,125,000$ & $65.9 \%$ & 79.9 \\
\hline Hungary & $9,905,596$ & $5,873,100$ & $6,176,400$ & $59.3 \%$ & 61.9 \\
\hline Kosovo & $1,804,838$ & 377,000 & 377,000 & $20.9 \%$ & 20.7 \\
\hline Latvia & $2,231,503$ & $1,369,600$ & $1,503,400$ & $61.4 \%$ & 68.2 \\
\hline Lithuania & $3,555,179$ & $2,103,471$ & $2,103,471$ & $59.2 \%$ & 59.5 \\
\hline Macedonia & $2,066,718$ & 906,979 & $1,057,400$ & $43.9 \%$ & 50.9 \\
\hline Moldova & $4,320,748$ & 850,000 & $1,333,000$ & $19.7 \%$ & 30.9 \\
\hline Montenegro & 672,180 & 294,000 & 303,480 & $43.7 \%$ & 45.9 \\
\hline Netherlands & $16,715,999$ & $14,304,600$ & $14,872,200$ & $85.6 \%$ & 88.3 \\
\hline Norway & $4,660,539$ & $4,235,800$ & $4,431,100$ & $90.9 \%$ & 94.4 \\
\hline Poland & $38,482,919$ & $20,020,362$ & $22,452,100$ & $52.0 \%$ & 58.4 \\
\hline Portugal & $10,707,924$ & $4,475,700$ & $5,168,800$ & $41.8 \%$ & 48.0 \\
\hline Romania & $22,215,421$ & $7,430,000$ & $7,786,700$ & $33.4 \%$ & 35.5 \\
\hline Serbia & $7,379,339$ & $3,300,000$ & $4,107,000$ & $44.7 \%$ & 56.2 \\
\hline Slovakia & $5,463,046$ & $3,566,500$ & $4,063,600$ & $65.3 \%$ & 74.2 \\
\hline Slovenia & $2,005,692$ & $1,300,000$ & $1,298,500$ & $64.8 \%$ & 64.9 \\
\hline Spain & $40,525,002$ & $29,093,984$ & $2,909,984$ & $71.8 \%$ & 62.2 \\
\hline
\end{tabular}




\begin{tabular}{|l|c|c|c|c|c|}
\hline \multirow{2}{*}{ Country } & \multirow{2}{*}{ Population } & \multicolumn{2}{|c|}{ Number of Internet users } & \multicolumn{2}{|c|}{ Access in\% } \\
\cline { 3 - 6 } & & $\mathbf{2 0 0 9}$ & $\mathbf{2 0 1 1}$ & $\mathbf{2 0 0 9}$ & 2011 \\
\hline Sweden & $9,059,651$ & $8,085,500$ & $8,397,900$ & $89.2 \%$ & 92.4 \\
\hline Switzerland & $7,604,467$ & $5,739,300$ & $6,152,000$ & $75.5 \%$ & 80.5 \\
\hline Ukraine & $45,700,395$ & $10,354,000$ & $15,300,000$ & $22.7 \%$ & 33.9 \\
\hline United Kingdom & $61,113,205$ & $46,683,900$ & $51,442,100$ & $76.4 \%$ & 82.0 \\
\hline
\end{tabular}

Source: http://www.internetworldstats.com/stats4.htm\#europe

Another significant measure of modernization processes and, in a way, of being "connected" to the world economy is the influx of direct investment. According to the figures provided by the Economist Intelligence Unit in London, far less than 10\% of the global volume of direct investments (see Table 3) came to Eastern Europe (including the whole proSoviet area) in the $1990^{\mathrm{s}}$ and in the early $21^{\text {st }}$ century. The share of this group of countries in the volume of global investments is growing slowly but steadily. However, there is clear asymmetry in the influx of foreign direct investments to individual Central and Eastern European countries. In 2006 the value of foreign direct investments in Poland was US\$ 12.6 billion, in Romania - US\$ 7.7 billion, in the Czech Republic - US\$ 5.4 billion, in Hungary - US\$ 5.1 billion, in Bulgaria - US\$2.6 billion, and in Slovakia - US\$2.2 billion. In the same year the value of foreign direct investments which came to Ukraine was US\$ 4.9 billion. The investments which came to Belarus and Moldova - if any - were worth under US\$ 100 thousand and were not identified ${ }^{35}$. This means another line of the civilizational division of Central and Eastern European countries into those which attract foreign investment i.e. which are "connected" to the financial "bloodstream" of the world economy and into those "disconnected". The former are European Union member states. The latter are chiefly countries outside the EU. At the same time this stratification is an opportunity for some of the Central and Eastern European countriesmembers of the EU to join the center of the world economy while it also

35 World investment prospects to 2011. Foreign direct investment and the challenge of political risk http://graphics.eiu.com/upload/WIP_2007_WEB. pdf, p. 34. 
means the reduction of those outside the EU to the status of peripheries or semiperipheries.

Table 3: The Structure of investment influx on a global scale in US\$ billion

\begin{tabular}{|l|r|r|r|c|}
\hline Countries & 1997 & 2000 & 2003 & \multicolumn{1}{c|}{2006} \\
\hline World & 491.8 & 1408.3 & 563.4 & 1335.1 \\
\hline North America & 114.9 & 380.8 & 60.0 & 252.7 \\
\hline Western Europe & 151.1 & 718.3 & 27.0 & 554.8 \\
\hline Eastern Europe & 24.1 & 29.5 & 35.1 & 105.9 \\
\hline Asia and Pacific & 111.0 & 165.9 & 110.9 & 238.6 \\
\hline South America and the Caribbean & 73.6 & 98.3 & 46.9 & 102.5 \\
\hline Near East & 7.1 & 6.6 & 14.2 & 46.2 \\
\hline
\end{tabular}

Source: World investment prospects to 2011. Foreign direct investment and the challenge of political risk, http://graphics.eiu.com/upload/WIP_2007_WEB. pdf, p. 19.

\section{INSTITUTIONAL TIES AS AN ELEMENT OF THE INTERNATIONAL ORDER IN CENTRAL AND EASTERN EUROPE}

The degree of institutionalization is a significant element of the characteristics of the international order and a factor of its maturity and stability. A feature of the Central and Eastern European area is asymmetry of institutional ties vital for the structure and functioning of the international order and the absence of an organization that could comprise all the countries in the area and act for their international actor status and identity. The one closest to this status is the Central European Initiative, which, however, does not cover the Baltic republics, while extending - despite controversies - over two countries outside of the area albeit closely connected with it: Austria and Italy (see Table 4 ). Therefore, there are varied or even diffused institutional ties between the countries of this area.

The structure of institutional ties between Central and Eastern European countries is another confirmation of their stratification or even 
different geopolitical orientations. Some of the countries have been included in the Euro-Atlantic security and integration structures such as NATO and EU. Poland, the Czech Republic, Slovakia and Hungary, and recently Estonia and Slovenia, have become members of the fairly elitist "club", which is the OECD. This "club" - with some oversimplification - is composed of the states which constitute the central area of present-day world economy. On the other hand, Belarus, Moldova and Ukraine are members of the CIS; Moldova and Ukraine are members of the GUAM, while only Belarus is part of the Collective Security Treaty Organization (ODKB), whose foundations were laid by the Tashkent Treaty signed in May 1992. The key role in this organization is played by Russia. Lithuania, Latvia, Estonia and Poland are, in turn, members of the Council of the Baltic Sea States. All these states are members of the United Nations, which is a general organization comprising 193 member states and members of the OSCE, which is a regional Euro-Atlantic organization comprising 56 member states, including the United States, Canada, Russia and the former Asian republics of the former Soviet Union. Belarus is the only Central and Eastern European country, which is not a member of the Council of Europe, which comprises 47 states. The subregional organization within the area, which was founded in 1991, is the Vysehrad Group with Poland, the Czech Republic, Slovenia and Hungary as its members.

\section{NORMS AS AN ELEMENT OF THE INTERNATIONAL ORDER IN CENTRAL AND EASTERN EUROPE}

Norms can be defined as behavioral patterns associated with the imperative to implement specific values or with the prohibition to act against them. In international relations they can assume the form of international law norms, political norms called "soft law" or even the form of moral norms. Under the conditions of evolution of the post-Cold War international order, Central and Eastern European states have actively participated and still do in negotiating and implementing the norms vital for this order's functioning. Especially significant seem to be the norms serving to mold the military order after the end of the two-bloc confron- 
Table 4: Central and Eastern European States' membership of international organizations

\begin{tabular}{|c|c|c|c|c|c|c|c|c|c|c|c|c|}
\hline Country & $\zeta$ & 덩 & 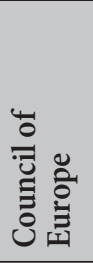 & 을 & 屈 & 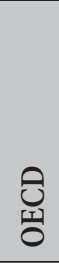 & 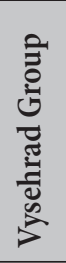 & 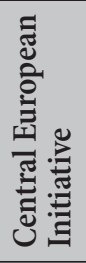 & 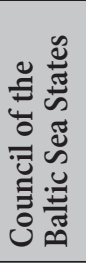 & $\tilde{y}$ & 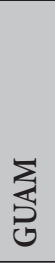 & 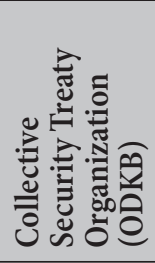 \\
\hline Albania & $x$ & $x$ & $x$ & $x$ & & & & $\times$ & & & & \\
\hline Belarus & $x$ & $x$ & & & & & & $x$ & & $\times$ & & $\times$ \\
\hline Bosnia and Herzegovina & $\times$ & $x$ & $\times$ & & & & & $x$ & & & & \\
\hline Bulgaria & $x$ & $\times$ & $x$ & $x$ & $x$ & & & $x$ & & & & \\
\hline Croatia & $x$ & $x$ & $x$ & $x$ & & & & $x$ & & & & \\
\hline Montenegro & $x$ & $x$ & $x$ & & & & & $x$ & & & & \\
\hline Czech Republic & $x$ & $x$ & $x$ & $x$ & $x$ & $\times$ & $\times$ & $x$ & & & & \\
\hline Estonia & $x$ & $x$ & $x$ & $x$ & $x$ & $x$ & & & $\times$ & & & \\
\hline Lithuania & $x$ & $x$ & $x$ & $x$ & $x$ & & & & $x$ & & & \\
\hline Latvia & $x$ & $x$ & $x$ & $x$ & $x$ & & & & $x$ & & & \\
\hline Macedonia & $x$ & $x$ & $x$ & & & & & $x$ & & & & \\
\hline Moldova & $x$ & $x$ & $x$ & & & & & $x$ & & $x$ & $\times$ & \\
\hline
\end{tabular}




\begin{tabular}{|c|c|c|c|c|c|c|c|c|c|c|c|c|}
\hline Country & Z & $\begin{array}{l}\text { 더 } \\
\text { ல }\end{array}$ & 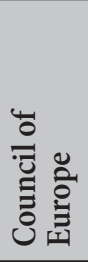 & 号 & P & తి & 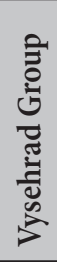 & 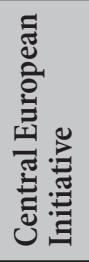 & 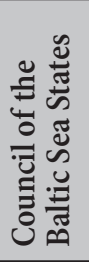 & $\ddot{U}$ & $\sum_{S}$ & 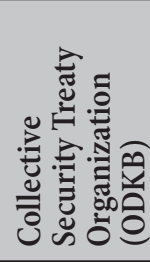 \\
\hline Poland & $x$ & $x$ & $x$ & $x$ & $x$ & $x$ & $\times$ & $x$ & $x$ & & & \\
\hline Romania & $\times$ & $\times$ & $\times$ & $\times$ & $\times$ & & & $x$ & & & & \\
\hline Serbia & $x$ & $x$ & $x$ & & & & & $x$ & & & & \\
\hline Slovakia & $x$ & $x$ & $\times$ & $\times$ & $\times$ & $x$ & $\times$ & $\times$ & & & & \\
\hline Slovenia & $x$ & $x$ & $x$ & $x$ & $x$ & $x$ & & $x$ & & & & \\
\hline Ukraine & $\times$ & $\times$ & $\times$ & & & & & $\times$ & & $\times$ & $x$ & \\
\hline Hungary & $\times$ & $\times$ & $\times$ & $x$ & $x$ & $x$ & $x$ & $\times$ & & & & \\
\hline
\end{tabular}

Source: Author's own compilation based on the website of the aforementioned organizations. 
tation (see Table 5). In this field, the Central and Eastern European states are parties to all-European or Euro-Atlantic agreements, thereby jointly shaping the international order.

Table 5: Central and Eastern European states as parties to international agreements significant for the military order

\begin{tabular}{|l|c|c|c|c|c|}
\hline Country & CFE & $\begin{array}{c}\text { Open } \\
\text { Skies } \\
\text { Treaty }\end{array}$ & $\begin{array}{c}\text { Confidence- } \\
\text {-Building } \\
\text { Measures }\end{array}$ & $\begin{array}{c}\text { The Code of } \\
\text { Conduct on } \\
\text { Politico-Military } \\
\text { Aspects of Security }\end{array}$ & $\begin{array}{c}\text { European } \\
\text { Security } \\
\text { Charter }\end{array}$ \\
\hline Albania & & $\times$ & $\times$ & $\times$ & $\times$ \\
\hline Belarus & $\times$ & $\times$ & $\times$ & $\times$ & $\times$ \\
\hline Bosnia and & & $\times$ & $\times$ & $\times$ & $\times$ \\
\hline Herzegovina & $\times$ & $\times$ & $\times$ & $\times$ & $\times$ \\
\hline Bulgaria & & $\times$ & $\times$ & $\times$ & $\times$ \\
\hline Croatia & $\times$ & $\times$ & $\times$ & $\times$ & $\times$ \\
\hline Montenegro & & $\times$ & $\times$ & $\times$ & $\times$ \\
\hline Czech Republic & $\times$ & $\times$ & $\times$ & $\times$ & $\times$ \\
\hline Estonia & $\times$ & $\times$ & $\times$ & $\times$ & $\times$ \\
\hline Lithuania & $\times$ & $\times$ & $\times$ & $\times$ & $\times$ \\
\hline Latvia & $\times$ & $\times$ & $\times$ & $\times$ & $\times$ \\
\hline Macedonia & & $\times$ & $\times$ & $\times$ \\
\hline Moldova & $\times$ & $\times$ & $\times$ & $\times$ \\
\hline Poland & $\times$ & $\times$ & $\times$ & $\times$ \\
\hline Romania & $\times$ & $\times$ & $\times$ & $\times$ \\
\hline Serbia & $\times$ & $\times$ & $\times$ & $\times$ \\
\hline Slovakia & $\times$ & $\times$ & $\times$ & $\times$ \\
\hline Slovenia & $\times$ & $\times$ & $\times$ & $\times$ \\
\hline Ukraine & $\times$ & $\times$ & $\times$ & $\times$ \\
\hline Hungary & $\times$ & $\times$ & $\times$ & $\times$ \\
\hline
\end{tabular}

Source: Author's own compilation based on the data from the websites of the aforementioned agreements. 
A significant element of change in the process of the functioning of norms in the Euro-Atlantic area after the Cold War is the substantial extension of the catalogue of mutually agreed-on norms, principles and rules regulating the behavior of states, and the diversity of their binding force. Along with documents creating a kind of "soft law" i.e. binding in the political sense, international-law regulations which are "classical" international regimes have appeared. Both of them mean that an important element of the international order and its analysis is the rise, application, change and the collapse of particular rules of the game. Underlying them is the conviction that social behaviors are molded by specific rules of the game; interaction processes and the meaning of individual behaviors on either side being mutually clear and intelligible ${ }^{36}$.

The first group of regulations, those politically binding, comprise inter alia decisions concerning confidence and security building measures, documents of CSCE/OSCE conferences, CSCE 1990 and 1991 regulations on human rights, or the Code of Conduct on Politico-Military Aspects of Security adopted during the CSCE Budapest summit and the European Security Charter adopted during the OSCE summit in Istanbul in 1999. With the specificity of the domain of regulation of particular instruments taken into account, the Central and Eastern European states are parties to these agreements. The accords concerning the four generations of confidence and security building measures contribute to the transparency of military activities, to the reduction of the probability of unexpected attack, and thereby to raising the level of security and the feeling thereof. They denote a change in the way of thinking by European states about military activities and are an important element of the organization of the international environment, consequently, of its order ${ }^{37}$.

A similar role is exercised by the Code of Conduct on Politico-Military Aspects of Security. This document was negotiated in the 1990s. It contains directives and rules of conduct such as indivisible security and provision of it through cooperation; refusal to provide assistance to or support of

36 F.V. Kratochwil, International Order and Foreign Policy. A Theoretical Sketch of Post-War International Politics, Boulder 1978, p. 2.

37 See Z. Lachowski, Środki budowy zaufania i bezpieczeństwa w nowym środowisku międzynarodowym, "Sprawy Międzynarodowe" 2001, No. 2, p. 37 et seq. 
states which do not refrain from threat or use of force against other states; recognition of the democratic political control of military forces; provision of transparency in military activities; non-imposition of military domination over other states; no support of terrorist acts; and combating terrorism in all its forms ${ }^{38}$.

The European Security Charter adopted in November 1999 is a recapitulation and culmination in the evolution of thinking about the international order and security in the Euro-Atlantic area, which commenced with the end of the Cold War. Hence this document expresses changes which occurred in this area and identifies new threats and challenges. Special emphasis was placed on the creation and application of mechanisms serving to prevent conflicts. This means that the OSCE is becoming the principal instrument of early warning, preventive diplomacy and actions taken after the cessation of conflicts aimed at preventing their resumption ${ }^{39}$. The document shows the so-called dual approach to the provision of peace and international security. According to it, it is necessary to build confidence between people inside the states and to strengthen cooperation between them. Underlying this approach is the clear perception of the interior of present-day states as a source of destabilization for international security and even of threats to security. This means that neither European countries nor the United States and Canada are under threat of classical aggression from the outside. Consequently, territorial conquests, which were the main motive for the arms race, no longer define the policies of the Euro-Atlantic states ${ }^{40}$. Hence they recognize partnership, solidarity and transparency as the main principles of their security policies. This direction of thinking appears to be especially significant for counteracting the sources of instability in Central and Eastern European countries, in particular in the post-Soviet area and in the Balkans.

\footnotetext{
38 See Kodeks postępowania $w$ dziedzinie polityczno-wojskowych aspektów bezpieczeństwa, [in:] Prawo w stosunkach międzynarodowych, ed. S. Bieleń, Warszawa 1996, pp. 285-290.

39 See A.D. Rotfeld, Europe: the new transatlantic agenda, [in:] SIPRI Yearbook 2000. Armament, Disarmament and International Security, Oxford 2000, p. 206.

40 A.D. Rotfeld, Przyszłość kontroli zbrojeń, "Sprawy Międzynarodowe” 2001, No. 2, p. 11.
} 
The Central and Eastern European states are also parties to legally binding regulations essential for stabilizing the international environment. These include the 1990 CFE Treaty on conventional disarmament in Europe and the 1992 Open Skies Treaty. The former defined the conventional arms limits, especially offensive weapons, for the states-parties. The latter introduced air observation as an instrument verifying the observance of disarmament treaties in the area extending from San Francisco to Vladivostok. Both treaties are examples of the new quality of arms control mechanisms after the end of the Cold War because they are incorporated in the logic of the functioning of the cooperative security system, of which they are becoming a part. They are also an element of molding the international order, thereby contributing to the transparency of military activities, to the predictability of behaviors of individual countries and to the elimination of the possibility of unexpected attack. That is why, as B. Buzan indicated, they contribute to achieving the state of "mature anarchy" of the decentralized international environment ${ }^{41}$

\section{ALIGNMENT OF POWERS IN CENTRAL AND EASTERN EUROPE}

For centuries the structure of the alignment of forces identified through analysis - the so-called polarity of the international environment - has been one of the most essential parameters of international order. In the history of humankind it was unipolar under the conditions of domination by one empire, e.g. the Roman empire, multipolar with the classic mechanism of the balance of powers as was the case with the period from the Westphalian Treaty (1648) to the end of World War II, or bipolar during the Cold War. At the turn of the twentieth century it was believed that the post-Cold War international order was a unipolar one with the hegemonic position of the United States. However, at the end of the first decade of the twenty-first century, Richard Haass formulated the view that the

41 B. Buzan, People, States and Fear: an Agenda for International Security Studies in the Post Cold War Era, Brighton 1999, p. 176. 
feature of present-day international relations was a turn towards nonpolarity. He believes that the world is no longer dominated by one, two or several superpowers, but that its feature is the existence of dozens of diverse actors with varied capabilities and the forms of their use in the international arena ${ }^{42}$. The grounds for the evolution of polarity in the international global order and for a challenge to US unipolar domination are created by the process of the simultaneous growth of power in many states, which Fareed Zakaria terms "the rise of the rest"43. This is accompanied by the comparative weakening of the US international position and by dilemmas over the US international role ${ }^{44}$.

To resolve this discussion is significant for the analysis of the position of Central and Eastern Europe in the structure of the alignment of forces in the international global order. It should be remembered, however, that the notion of power and its constituents are a dynamic, evolving phenomena and considerable redefinitions occur here. First of all, the non-military elements of the power of present-day states are gaining in importance and in this context the military components of power are comparatively losing their significance. In the mid-1990s, Henry Kissinger, an avowed follower of the realist school, showed that the problems that could be solved by military means tended to be limited while military power was less and less important for solving predictable international crises ${ }^{45}$. Instead, the importance of economic and technological factors of power, in particular the so-called technopower, is systematically growing. The grounds for its development are created by scientific research, especially in the field of high technologies for information processing. Joseph Nye made the subject of his analysis the phenomenon of "soft power" identified with attractiveness and the ability to change the behavior of other entities (actors) by the "power" of patterns that they accept ${ }^{46}$. Consequently, in the presentday, with the increasingly complex international environment we are

42 R.N. Haass, The Age of Nonpolarity, "Foreign Affairs" 2008, Vol. 87, p. 44.

43 F. Zakaria, The Post-American World, New York 2011, p. 1 et seq.

44 J. Mearsheimer, Imperial by Design, “The National Interest” 2011, Vol. 111, pp. 16-34.

45 H. Kissinger, We live in an age of transition, "Deadalus" 1995, Vol. 124, p. 102.

46 See J.S. Nye, Soft Power. The Means of Success in World Politics, New York 2004. 
dealing more and more with the diffusion of power and diversity or even ambiguity of its sources. This assessment will not be changed, paradoxically, by the unprecedented, albeit comparatively declining, hegemony of the United States. This diffusion of power is also contributed to by nongovernmental actors, especially transnational corporations which, because of their technological and financial capabilities, are becoming carriers of power in the international arena along with the states. This means that the problem of power in international relations cannot be examined only and exclusively from the state-centric perspective.

Table 6: Capabilities of Central and Eastern European States

\begin{tabular}{|l|c|c|c|}
\hline Country & $\begin{array}{c}\text { Demographic } \\
\text { potential in million } \\
\text { (2011 est.) }\end{array}$ & $\begin{array}{c}\text { GDP after IMF for } \\
\text { 2010 in . billion }\end{array}$ & $\begin{array}{c}\text { Military spending in } \\
\text { 2010 in US\$ million }\end{array}$ \\
\hline Albania & 3.0 & 111.8 & 201 \\
\hline Belarus & 9.6 & 54.7 & 726 \\
\hline $\begin{array}{l}\text { Bosnia and } \\
\text { Herzegovina }\end{array}$ & 4.6 & 18.4 & 232 \\
\hline Bulgaria & 7.1 & 47.7 & 698 \\
\hline Croatia & 4.5 & 60.8 & 1060 \\
\hline Montenegro & 0.66 & 4.0 & 55.8 \\
\hline Czech Republic & 10.2 & 192.2 & 2529 \\
\hline Estonia & 1.3 & 18.7 & 336 \\
\hline Lithuania & 3.5 & 36.3 & 268 \\
\hline Latvia & 2.2 & 24.0 & 145 \\
\hline Macedonia & 2.1 & 9.3 & 19 \\
\hline Moldova & 4.3 & 6.1 & $\mathbf{8 3 8 0}$ \\
\hline Poland & 38.4 & 468.6 & 2164 \\
\hline Romania & 21.9 & 161.6 & 920 \\
\hline Serbia & 7.3 & 39.1 & 1010 \\
\hline Slovakia & 5.5 & 89.0 & 78.8 \\
\hline Slovenia & 2.0 & & \\
\hline Ukraine & 45.1 & & \\
\hline
\end{tabular}




\begin{tabular}{|l|c|c|c|}
\hline Country & $\begin{array}{c}\text { Demographic } \\
\text { potential in million } \\
(2011 \text { est.) }\end{array}$ & $\begin{array}{c}\text { GDP after IMF for } \\
\text { 2010 in . billion }\end{array}$ & $\begin{array}{c}\text { Military spending in } \\
\text { 2010 in US\$ million }\end{array}$ \\
\hline Hungary & 9.9 & 130.4 & 1323 \\
\hline Russia & 138.7 & 1479.8 & 52586 \\
\hline USA & 313.2 & 14582.4 & 698281 \\
\hline
\end{tabular}

Source: Author's own compilation based on http://www.internetworldstats.com/europa. htm; http://milexdata.sipri.org/result.php4; http://www.mongabay.com/igapo/world_statistics_by_pop.htm; https://www.cia.gov/library/publications/the-world-factbook/ fields/2119.html; www.worldbank.org/DATASTATISTICS/Resources/GDP_PPP. PDF

Regardless of the foregoing remarks on the progressive complexity and variability of power in present-day international relations, the alignment of powers in Central and Eastern Europe will be analyzed in a state-centric approach and with reference to fairly traditional, measurable elements of power such as the demographic potential, gross national income and military expenditure (see Table 6). In the context of the aforementioned elements of power it should be clearly emphasized that the states in the area in question, especially as compared with their environment, do not have sufficient capabilities to enable them to exert a significant effect on the international environment. Hence some states in this area are objects of international influence or stakes in the geopolitical game, which also largely applies to Ukraine.

The aforementioned assessment showing the deficit of the states' potential in this area, which could enable them to exert influence on the international environment, cannot be changed by the special position of Poland. If we add the population size, the volume of national income and military spending, Poland appears to have the largest potential of all the states in this Central and Eastern European area. The demographic potential of the majority of states in the area, except Ukraine, Poland and Romania, does not exceed 10 million, the Czech Republic's population being at the level of 10 million. Poland's national income is twice as high as that of the Czech Republic, which occupies the second position among the countries in the area; and more than twice as much as Romania's (third position) and 2.5 times as high as Ukraine's income (fourth position). 
There are similar differences in the military spending potential. Poland's military expenditure is two and a half times higher than that of Ukraine, four times as high as Romania's and the Czech Republic's spending, and it exceeds the expenditure of the remaining states in the area several or even a dozen times. We should remember, however, that in the case of Poland and Ukraine, the difference in military spending does not mean that Ukraine's military capabilities are lower than those of Poland.

The attempt to measure and compare the potential of Central and Eastern European states explicitly confirms the aforementioned opinion that in aggregate terms Poland has the largest potential. It even appears to be, except for the military capabilities, the hegemon of the area. This position - in accordance, for example, with the mechanism (characteristic of the neorealist school) of structural power ${ }^{47}$ - is strengthened by Poland's membership of NATO and EU. Does that mean, however, that Poland is capable of exercising the role of the leader in the area? Despite some politicians' aspirations, Poland does not have sufficient capabilities (even with a surplus of potential) to exercise this role and does not appear to be wanting such a role. This is confirmed by the response of Hungary supported by Austria to the conception of the Eastern Partnership promoted by Poland. Hungary is trying to promote a rival strategy: the Danube partnership ${ }^{48}$.

The comparative difference in capabilities of the Central and Eastern European states, particularly when compared with the resources of the international environment, results in especially the pro-Soviet countries such as Ukraine, Moldova and Belarus having a stake in the game of international influence, which confirms that the international order in this part of Europe has not been molded yet. For its completion, of fundamental significance Ukraine's future and the question whether this country will remain tied with the Euro-Atlantic institutions or in the Russian zone of influence.

47 For more see J. Czaputowicz, Teorie stosunków międzynarodowych. Krytyka i systematyzacja, Warszawa 2007, p. 179 et seq.

48 “Gazeta Wyborcza”, 7.11.2009. 
Russia indisputably strives to rebuild its imperial position and zone of influence in the post-Soviet area, which particularly concerns Ukraine and Belarus but also Moldova. At this level of political thought, the grounds for such actions are provided by the so-called nostalgic conception, which assumes the rebuilding of Russia's position and role as a world power. This purpose is to be served by establishing something like a Slavonic union whose indispensable members would be Ukraine and Belarus. Regardless of her political visions, however, the practice of Russia's policy is to exert influence on the international environment, especially Ukraine, by raw materials and energy soras but also by military ones (the Black Sea Fleet based in Ukraine's territory), by using the Russian minority and by the pressure of the Russian media. The dominant instruments in these actions appear to be "hard ones", although Russia, taking advantage of the good and fairly common knowledge of Russia in the post-Soviet area, does not neglect the use of "soft instruments" such as propaganda activities.

In the activities of Western European countries aimed at supporting the European political standards in the pro-Soviet area the dominant instruments are the "soft ones" meant to promote democratic institutions and human rights. There area of conceptions of supporting development processes and modernization. The instrument serving this purpose is the "Eastern Partnership" initiative, backed up in particular by Poland and Sweden, ${ }^{49}$ which is, essentially, an extension of the European Neighbourhood Policy implemented by the European Union. Poland aspires to take part in shaping the eastern dimension of the European Union's policies ${ }^{50}$ and in stimulating the EU's active involvement in the pro-Soviet area, which clearly clashes with Russia's interests.

To sum up, we should emphasize that the proposition that the Central and Eastern European area is not a united and cohesive region in international relations has been successfully verified. It is an area of dynamic changes with varied implications for the process of molding the international order in post-Cold War Europe. First, this is an area where a division

49 See B. Wojna, M. Gniazdowski (ed.), Partnerstwo Wschodnie - raport otwarcia, Warszawa 2009.

50 See B. Piskorska, Wschodni wymiar polityki Unii Europejskiej, Toruń 2008. 
has been effected and is being consolidated. It is especially noticeable in reference to shared political standards and institutional ties, the distinct line of division occurring between the states in the area that belong to the European Union and NATO and the states outside of these structures. Second, regardless of the aforementioned divisions, the Central and Eastern European states are an equal partner in the process of molding and implementing norms significant for military order in Europe. Third, under the conditions of comparative differences in potentials, especially when compared with the international environment, some countries in the Central and Eastern European area have a stake in the game of international influence, which is an additional argument for the proposition that the process of building the international order in this part of Europe has not yet been completed. 